\title{
STARENJE I STAROST - SADAŠNJOST I BUDUĆNOST STANOVNIŠTVA
}

\section{Sažetak}

Starenje stanovništva jedno je od važnijih pitanja budućnosti i društvenog razvoja velikog broja zemalja. Cinjenica je da prilagođenost na starost ne ovisi samo o biološkim i psihološkim faktorima, već i o vanjskim faktorima, kao što su socijalna okolina, obiteljske prilike, stambeni uvjeti i sistemi podrške koji u nekim sredinama postoje, a usmjereni su na pomoć starim osobama. $\mathrm{Na}$ globalnoj razini uočava se trend povećanja svjetskog stanovništva do 2050. na 9,4 milijarde ljudi, od čega će 7,8 milijardi svjetske populacije pripadati nerazvijenim zemljama. Podaci o demografskim kretanjima u većini razvijenih zemalja ukazuju na potrebu novih naucnih, ali i političkih pristupa u budućem oblikovanju strategije zaštite za stare osobe. Dok evropsko stanovništvo sve više stari, čime se u nadolazećim godinama očekuje pad broja stanovnika u Europi, u Sjedinjenim Državama prisutan je suprotan trend. Demografska dimenzija globalizacije pokazuje njezina dva lica. Ono prvo lice bogatih zemalja s depopulacijskim trendom (Zapad) i ono drugo, siromašno s hiperpopulacijom. Globalni trendovi bi se trebali kretati u pravcu promoviranja demografske obnove, zapošljavanja u Evropi kroz veći broj poslova $i$ duži radni vijek, prihvaćanje i integriranje imigranata u Evropi te održive javne finansije u Evropi koje će jamčiti adekvatnu socijalnu sigurnost i jednakost medu generacijama.

Ključne riječi: starenje, starost, demografsko starenje, socijalna politika, socijalna sigurnost

\footnotetext{
${ }^{1}$ Dr sc. Hariz Šarić, Odsjek za socijalni rad Filozofskog fakulteta Univerziteta u Tuzli, email: hariz.saric@untz.ba.

${ }^{2}$ Mr. sc. Sena Družić, Vlada Unskosanskog kantona, e-mail: sena_druzic@yahoo.ca.

${ }^{3}$ Dr. sc. Alisabri Šabani, Fakultet za kriminalistiku, kriminologiju i sigurnosne studije, Univerziteta u Sarajevu, e-mail: asabani@fkn.unsa.ba
} 


\section{Uvod}

Starije osobe čine specifičnu društvenu grupu čije se potrebe, proistekle iz procesa starenja, a javljaju u oblasti socijalne politike, kao organizovano, aktivno angažovanje društvene zajednice u obezbjeđivanju životnih uslova, odnosno socijalne sigurnosti starih osoba. Ove aktivnosti, kao i njihova osnova zasnovana na naučnom pristupu problemima starih i starosti, čine dio socijalne politike, koji se često naziva i politika starenja.

Neodvojivo od osnovnih pitanja starenja i starosti, sastavni dio pitanja čine i pitanja porodične solidarnosti. Porodica kao najznačajnija društvena grupa u životu pojedinca i društva u cjelini zauzima, shodno tome, važno mjesto i dijelove aktivnosti socijalne politike.

Mjere socijalne politike koje su rezultat aktivnosti i usluga različitih društvenih institucija i ustanova usmjerenih na porodicu nazivaju se često i porodičnom politikom (Burić, O. 1980:189).

U ovoj oblasti socijalne politike, kojoj tek predstoji ozbiljan razvoj, također su važna pitanja vezana za porodicu starih ljudi, s obzirom na sve češću pojavu njene ekonomske deprivacije i socijalne izolacije.

\section{Definisanje pojmova}

Starenje stanovništva jedno je od važnijih pitanja budućnosti i društvenog razvoja velikog broja zemalja. Utjecaj i posljedice relativno brzog povećanja udjela stare populacije u društvu očituje se u najvažnijim sektorima, kao što su privreda, zdravstvo, socijalna zaštita i brojnim drugim. Iako se starosti kao fenomenu u politici zaštite često prilazi na individualnoj razini, nastojeći pronaći odgovore na specifičnosti potreba stare osobe, ipak se danas razvijena društva izrazito trude da fenomenima starosti i starenja pristupe sa aspekta šire društvene razine. Takav pristup svoje utemeljenje ima i u činjenici da prilagođenost na starost ne ovisi samo o biološkim i psihološkim faktorima, već i o vanjskim faktorima, kao što su socijalna okolina, obiteljske prilike, stambeni uvjeti i sistemi podrške koji u nekim sredinama postoje, a usmjereni su na pomoć starim osobama (Bouillet, 2003.). 
Podaci o demografskim kretanjima u većini razvijenih zemalja ukazuju na potrebu novih naučnih, ali i političkih pristupa u budućem oblikovanju strategije zaštite za stare osobe. Za razliku od razvijenih zemalja, evropske zemlje u razvoju još uvijek su usmjerene u nastojanju da se tek razviju suvremeni sistemi cjelovite zaštite o starim osobama, koji objedinjuje i državni i nevladin, privatni, profitni i neprofitni sektor zaštite (Havelka, Despot Lučanin i Lučanin, 2000.).

Pod pojmom starost obično se podrazumijeva period nakon 65. godina života, ali čitavu kategoriju možemo podijeliti na dvije grupe (do 75 i više od 75 godina), s tim i sve starije na "mlađe“ i „starije“ (Mesec, 2000.). Definiranje starosti ipak nije isključivo pitanje nečije hronološke dobi i funkcionalnih sposobnosti već i odnos kvalitete nečijeg života, sistem vrijednosti i obilježja sredine u kojoj neka osoba živi (Bouillet, 2003.). Stariji ljudi nisu homogena skupina i ne doživljavaju sebe kao odvojenu populacijsku skupinu, nego su integrisani dio zajednice u kojoj aktivnim uključivanjem žive, rade i stvaraju.

Starost je vrijeme kad život dobija nove duhovne dimenzije i prednosti kojih nije bilo u mladosti. Otvaraju se šanse razvoja i mogućnosti ostvarenja preorijentacije radnih aktivnosti. Aktivno, zdravo starenje uključuje prilagodbu novim okolnostima, spoznajama, te stalno učenje i otkrivanje prednosti starenja i starosti.

\section{Definisanje demografskog starenja stanovništva}

Proces starenja stanovništva ili demografskog starenja stanovništva, nacije ili svijeta u cjelini, za razliku od individualnog, podrazumijeva određene demografske kriterije. Kao što je individualni proces starenja stanovništva čovjeka fundamentalno određen biološkim promjenama, ovdje su fundament demografske promjene, kao i kriterij prema kojima se ovaj proces određuje.

U demografiji je, za razliku od biologije, znatno više prisutna konvencionalna kategorija (prije svega, pojmovi i kriteriji prihvaćeni od većine stručnjaka), koji se određuju na osnovu empirijskih saznanja o nekim prosječnim indikatorima starenja stanovništva. 
Najznačajniji osnovni kriterij za određivanje procesa starenja stanovništva donijeti su na Svjetskoj skupštini o starenju 1982. godine.

Proces starenja stanovništva odražava se i mjeri pokazateljima kao što su: srednja (prosječna) starost, procent ljudi u okviru stanovništva koji se definišu kao „stari“ 60 ili 65 godina i više, odnos ljudi starijih od 60 godina prema djeci mlađoj od 15 godina i procent stanovništva iznad određenog broja godina, koji odgovara preostalom očekivanom životnom vijeku od 10 ili 15 ili 20 godina.

Prema ovim kriterijima utvrđena su mjerila, odnosno granice, poslije kojih smatramo, da je određeno stanovništvo ušlo u proces demografskog starenja. Stanovništvo u kome je:

- Procent učešća stanovništva iznad 60 godina, veći od 12\% (osnovni pokazatelj),

- Prosječna starost stanovništva iznad 30 godina (ukupan broj godina podijeljen sa brojem stanovnika),

- Odnos broja stanovnika starijih od 60 godina prema broju djece ispod 15 godina veći od 0,40 (indeks starenja ),

- Procent stanovništva iznad 40 godina veći od 35\% od ukupnog broja, može se smatrati starim stanovništvom, u demografskom smislu.

Definisanje procesa starenja stanovništva ili demografskog starenja najčešće se svodi na utvrđivanje tempa povećavanja i nivoa učešća stanovništva starog 60 ili 65 i više godina u ukupnom stanovništvu.

Granice se ipak mogu određivati samo uslovno, jer postoji velika raznolikost faktora koji utječu na procese starenja.

Neposredni utjecaj na demografsku strukturu stanovništva svakako imaju i rađanje (natalitet) i trajanje ljudskog života (očekivano trajanje životnog vijeka) i smrtnost (mortalitet) ljudi. Iz njihovog neposrednog djelovanja proistekle su i pomenute granice i odredbe demografske starosti stanovništva, a to se potvrđuje i demografskim istraživanjima. 
Prvi ili primarni uzrok demografskog starenja je sekularno opadanje fertiliteta (rađanje), a ne snaženje mortaliteta. Pri tome, starenje stanovništva odražava nivo fertiliteta, odnosno postoji obrnuta povezanost između stope nataliteta i proporcije starih osoba. Tako, nisko natalitetna područja imaju veći udio starijeg stanovništva (preko 60), iznad $10 \%$. U dužem periodu starenja stanovništva smanjuje se jezgro stanovništva fertilne dobi (15 - 30 godina), u odnosu na grupu od 30 - 49 godina gdje je rađanje znatno rjeđe, što dalje smanjuje ukupni fertilitet.

Smanjenje fertiliteta ubrzava proces starenja ukupnog stanovništva, jer odmah i direktno, postaje sve manji ukupan broj djece u stanovništvu.

Poslije određenog vremena taj se utjecaj proširuje na sve starosne grupe.

Ubrzavanje starenja izaziva, uslijed povećanog rizika smrti u dobi nakon 60. godina, i određeni porast opšte stope mortaliteta (Smolić-Krković, H. 1974).

Uz to, ako i očekivana dužina života raste, srazmjerno njoj uvećava se broj starijih u odnosu na ukupno stanovništvo, a u strukturi starijih se povećava broj izrazito starijih osoba.

Prema ovom mehanizmu, populacije sa visokim natalitetom su veoma mlade i obrnuto, sa niskim natalitetom su u poodmakloj starosti.

\section{Teorije o demografskom starenju}

Prema teoriji o demografskom preobražaju ili demografskoj tranziciji razlikuju se tri faze u demografskom razvoju stanovništva, od kojih su posljednje dvije u stvari, one koje označavaju proces starenja stanovništva prema opće usvojenim mjerilima (Izazov starosti : 1984:73).

1) Stanovništvo, prije demografskog prelaza ili tranzicije odlikuje se visokim natalitetom (bruto stopa reprodukcije 3,29) i visokim mortalitetom $(\mathrm{Q}=38,48)$

2) Stanovništvo za vrijeme demografskog prelaza ili tranzicije koji ima visok natalitet (bruto stopa reprodukcije 3,13) i nizak mortalitet $(\mathrm{Q}=$ $67,70)$ 
3) Stanovništvo koje je prošlo kroz demografski prelaz ili tranziciju ima nizak natalitet (bruto stopa reprodukcije 1,26) i nizak mortalitet $(\mathrm{Q}=$ 74,22).

Većina demografa se slaže da je generalni uzrok procesa starenja opšti rast i napredak čovječanstva, odnosno procesa civilizacije, što ustvari potvrđuje multikauzalnosti procesa, odnosno djelovanja više općih, posebnih i pojedinačnih uzroka.

Rast i napredak čovječanstva se odvija uz direktan utjecaj dva opća i međusobno povezana faktora.

a) industrijalizacije društva

b) urbanizacije društva.

Iz ovih općih faktora proizlazi niz posebnih, kao što su promjene profesionalnih, ekonomskih i kulturnih i demografskih osobina i posebno socijalne i prostorne pokretljivosti stanovnišstva.

Emigracija (pokretljivost, u smislu napuštanja matične države) koja zahvata mlado stanovništvo utiče na ubrzani proces demografskog starenja, a starenje stanovništva smanjuje opštu pokretljivost.

U procesu starenja stanovništva cijelog svijeta postoji apsolutno i relativno povećanje staračke populacije, a ona je sa stanovišta socijalno-zdravstvenih karakteristika i rezultat napretka medicine i posebno kontrole epidemijskih oboljenja.

Po teoriji demografske tranzicije taj će se rast i dalje nastaviti, dok će opadati natalitet i mortalitet.

\section{Karakteristike demografskog starenja u svijetu}

Demografsko starenje je starenje stanovništva kao cjeline:

- bilo na određenom geografskom području (naselje, oblasti, države, regije, kantona), bilo u svijetu u cjelini,

- posmatrano u određenom vremenskom periodu,

- projektovano (statističkim metodama) u budućnosti. 
U ovom odjeljku bit će prikazani osnovni demografski pokazatelji procesa starenja za svijet kao cjelinu. Jedan od zaključaka sa Svjetske skupštine o starenju (Beč, 1982) bio je da postoji velika vjerovatnoća da će 21. vijek, biti vijek starih ljudi. Ovakav zaključak se najpouzdanije zasniva na procjeni ukupnog broja stanovnika zemlje starijih od 60. godina. Taj broj raste, sa 214 miliona u 1950. godini na 590 miliona u 2000. godine, te se očekuje preko jedne milijarde 2025. godine. Mada će svaka zemlja pojedinačno biti pogođena, opće povećanje ima globalni značaj.

U toku pomenutih 75 godina ovaj rast povećan je za pet i više posto, dok se broj ukupnog stanovništva na zemlji povećao za tri posto.

Procent starih u ukupnom stanovništvu u ovom istom periodu porast će od $8,5 \%$ u 1950. godini na 13,7\% u 2025. godini. Dakle, postoji porast i u broju i u proporciji starih. U odnosu na strukturu starijeg stanovništva najspektakularniji je porast broja starih od 80 godina. Taj broj će u ovom periodu porasti od 15 miliona 1950. godine na 111 miliona 2025., dakle za 7,3 puta.

Pored toga, utvrđeno je da će najveći broj starih (preko 15 miliona) imati 13 zemalja, među kojima je Kina, Indija, SAD, Japan i Brazil, a od evropskih zemalja - Italija, Njemačka i Rusija. Očekuje se da će broj starih biti najveći u razvijenim regionima svijeta $(2025$ - 72\%), a pod tim se podrazumijeva Evropa, Australija, Japan, Novi Zeland, Sjeverna Amerika i zemlje bivšeg SSSR.

U posmatranom periodu uočena je ogromna raznovrsnost između zemalja, pa čak i dijelova jedne zemlje, ali ukupni opći svjetski trendovi, najbliži su ovim promjenama u regionima i zemljama u razvoju.

U manje razvijenim područjima svijeta, trendovi starenja bit će sporiji, ali će biti uravnoteženiji odnos između polova, što ima značaj za opstanak starijih (različiti prihod), za porodice (razlike u porodičnoj podršci) i za socijalne službe. U razvijenim regionima, već na uzrastu od šezdeset godina ima značajno više žena, a na uzrastu osamdeset i više godina ima dva puta više žena nego muškaraca. 
Stepen urbanizacije starih, odnosno život starih u gradu, također, će se povećati značajno više od porasta broja starih na seoskim, ruralnim područjima.

U 2000. godini oko 55\% starih živi u gradu, a u tom procesu više učestvuju žene što povećava specijalne probleme starijih žena na tim područjima. Staranje o veoma starim na seoskom području postat će poseban problem zbog njihove smanjene pokretljivosti, zdravstvene i socijalne zaštite, ali za seoska područja, očekuje se uravnoteženiji odnos između polova, što je, također, važan faktor. Za razvijene regione, karakterističan je i odnos između visokog rasta starih, sa smanjenjem ili bukvalno zanemarljivim porastom drugih dobnih grupa. Ove promjene mogu imati, značajne posljedice na odnos zavisnosti (odnos stanovništava od 0 do 14 i 60 i više, prema grupi aktivnih, 15 do 59 godina), ali i političke implikacije (rast broja starijih sa pravom glasa).

Međutim, starenje regiona može biti intenzivnije i dramatičnije u zemljama u razvoju. Ukoliko se nastavi opadanje fertiliteta, starenje će se znatno povećati, kao posljedica brojnosti generacija rođenih 50-tih i 60tih godina.

Utvrđivanje programa za stare sutra, omogućiti će se kroz brigu za omladinu danas, za koju se svi oni što odlučuju slažu da su opravdani i ogromni napori.

\section{Demografski portret starenja u Evropi}

Povodom Evropske godine starih ljudi i solidarnosti između generacija (1993) sačinjen je demografski portret starih u zemljama Evrope.

U posljednje tri decenije broj starih (60 i više godina) porastao je za skoro 50\%. Sve prognoze, zasnovane na očekivanoj dužini života, ukazuju da će se ovaj trend nastaviti i u budućnosti i da će 2020. godine u Evropi biti dvostruko više starijih nego 1960. godine (od 46,5 miliona na 100 miliona starih).

Prema popisu stanovništva iz 1999. godine u zemljama Evrope je bilo ukupno 68,6 miliona ljudi starijih od 60 godina, što čini $19,9 \%$ od 
ukupnog boja stanovnika. Utvrđeno je da postoji kontinuiran trend rasta broja starih, ali i trend daljeg starenja u okviru populacije starih. Dok je 60 -tih godina u populaciji starih od 60 godina bilo samo oko $10 \%$, ovo učešce je 90 -tih poraslo na skoro $17 \%$, dok se za 2020. godinu predviđa dalji rast na nivou od 19 do $22 \%$.

Utvrđene promjene ukazuju na rastuće potrebe $\mathrm{u}$ obezbjeđivanju materijalne sigurnosti, prije svega penzije, ali i zdravstvene i socijalne zaštite i potreba za solidarnim odnosom između generacija.

Napredak medicine i životnih uslova doveo je do rasta očekivane dužine života. U 1988. godini, prosjek očekivane dužine života bio je 78 godina za muškarce, a za žene 82,5 godina. U 1990. najviša očekivana dužina života je u Grčkoj, za muškarce (79,2 godine), a u Irskoj, najmanja (76,6 godina). Za žene Francuske najviša očekivana dužina života je 84,2 godine, dok je za žene Irske najniža (80,6 godina).

Činjenica je da je trend rasta očekivane dužine života u proteklih trideset godina za žene bio izraženiji nego za muškarce, iako je već 60-tih njihova očekivana dužina života bila viša nego za muškarce.

Napredovanjem demografskog starenja, i odnos između polova gubi ravnotežu u korist žena. Ova nejednaka distribucija ima posljedice i na porodične uslove starijih, pa među ženama ima znatno više udovica, $u$ dubokoj starosti neudatih i razvedenih.

Izvršena je analiza domaćinstava u kojima žive stariji (isključeni su stari koji žive u institucionaliziranim uslovima oko 5\%) koja pokazuje da od 1991. godine broj onih koji žive sami raste sa godinama života i skoro je trostruko veći u grupi sa 80 i više godina, nego kod onih sa 60-64 godine, i to važi i za žene i za muškarce.

U svakoj starosnoj grupi, postoje razlike u korist žena koje najmanje dvostruko, a i više, žive same. Na uzrastu 60-64 godine to je odnos 10\% (muškaraca) prema $20 \%$ (žena), da bi na uzrastu 80 i više godina bilo $27 \%$ muških samaca prema $57 \%$ žena.

Propisane godine starosti za odlazak u penziju su različite po pojedinim zemljama Evropske unije i to za muškarce od 60-67 godina i za žene od 
55-65 godina života. Utvrđeno je generalno, da radna angažovanost opada, i za muškarce i za žene već od 50 godina života, mada po zemljama ima različitosti.

Poslije 60-te godine života na tržištu rada je u 1991. godini bilo ukupno starijih ljudi i to 4,3 miliona muškaraca i dva miliona žena, ili $10 \%$ od ukupnog broja starijih. Stariji se u manjoj mjeri zapošljavaju kod poslodavaca, a u većoj mjeri su sami poslodavci ili privatnici, ili rade u porodičnim preduzećima.

Skoro četvrtina starijih radi u poljoprivredi, dok isti sektor zapošljava znatno manje mlađih (5,6\%). Manja je proporcija zaposlenih u industriji (23\%), a najveća u oblasti usluga (51\% muškaraca i 67\% žena). Stariji muškarci, češće nego žene, rade puno radno vrijeme.

\section{Populacijski trendovi u Evropi i Sjedinjenim Američkim Državama}

Dok evropsko stanovništvo sve više stari, čime se u nadolazećim godinama očekuje pad broja stanovnika u Europi, u Sjedinjenim Državama prisutan je suprotan trend. Hoće li ovakva demografska razlika ostaviti traga na transatlantske odnose i na koji način, pitanje je kojim se bave američki stručnjaci što je potvrdila i nedavna konferencija u Washingtonu. Sa 2,1 novorođenim djetetom na svaku ženu (što je obnovljiva razina) i $s$ postojanim prilivom imigranata, Sjedinjene Američke Države imaju najveći rast stanovništva među razvijenim zemljama. $S$ godišnjom stopom rasta od oko 1,3 posto, stanovništvo Sjedinjenih Američkih Država se utrostručilo se u 20. vijeku. Istovremeno se stanovništvo većine evropskih zemalja smanjuje i stari. Rastući broj ljudi u mirovinskoj dobi nije u ravnoteži s brojem stanovnika u radnoj dobi. Mlađe stanovništvo Evrope, koje predstavlja 16,9 posto stanovništva, smanjilo se za 25 posto u posljednjih 25 godina, a predviđanja govore o daljnjem padu. Usporedbe radi, 27,5 posto stanovništva Sjedinjenih Američkih Država mlađe je od 19 godina. Usprkos predviđenom povećanju prosjeka godina stanovništva u Sjedinjenim Američkim Državama, očekuje se da će broj mladih ljudi sposobnih za produktivan rad i vojnu službu ostati postojan. 
Demograf Nicholas Eberstadt kaže: "Predviđa se da će se umjereni do robusni rast stanovništva u Sjedinjenim Američkim Državama nastaviti, a da će u Zapadnoj Evropi broj stanovnika prestati rasti, a zatim se početi smanjivati. U roku od četiri do pet godina mortalitet u Evropi postat će veći od nataliteta i broj stanovnika počet će se smanjivati". Eberstadt dodaje da bi mladenački nazori i vrijednosti mlade i rastuće Amerike, te sve starije Evrope mogli uskoro dovesti do zategnutnosti u transatlantskim odnosima.

On prognozira da bi starije stanovništvo Evrope moglo biti opreznije u kooperaciji o pitanju međunarodne sigurnosti. Primjećuje, nadalje, da bi demografski jače Sjedinjene Američke Države mogle ocijeniti da njihovo partnerstvo $s$ demografski stagnirajućom Evropom gubi na vrijednosti. Stručnjaci objašnjavaju da je starije stanovništvo u principu manje produktivno i manje inovativno nego ono mlađe. Prema Eberstadtu, demografske razlike između Sjedinjenih Američkih Država i Evrope mogle bi negativno utjecati na jaku ekonomsku povezanost preko Atlantika. No Barbara Torrey iz Udruge za pitanja stanovništva ističe da su poboljšanja u zdravstvenoj zaštiti omogućila ljudima da budu zdraviji i žive dulje. Medicinska dostignuća su promijenila tradicionalne društvene trendove i učinila faktor godina manje važnim nego ikada prije. Prema istom autoru: "Činjenica je da se nitko, ni u Europi ni u Sjedinjenim Američkim Državama, ne ponaša u skladu sa svojim godinama. Dakle, nameće se pitanje koliko su godine uopće važne. U Italiji, primjerice, dvije trećine muškaraca u dobi između 25 i 30 godina još živi sa svojim majkama. Za mene to znači da 30 više nije znatno godište kao što je to bio slučaj prije 30 godina".

Populacioni trendovi u Evropi

\begin{tabular}{|l|l|}
\hline Godina & Stanovništvo u tisućama \\
\hline 1950. & 547,405 \\
\hline 1960. & 604,406 \\
\hline 1970. & 655,862 \\
\hline
\end{tabular}




\begin{tabular}{|l|l|}
\hline 1980. & 692,435 \\
\hline 1990. & 721,390 \\
\hline 2000. & 728,463 \\
\hline 2005. & 728,389 \\
\hline 2010. & 725,786 \\
\hline 2020. & 714,959 \\
\hline 2030. & 698,140 \\
\hline 2040. & 677,191 \\
\hline 2050. & 653,323 \\
\hline
\end{tabular}

Izvor: Prof. dr. sc. Anđelko Milardović "Globalizacija i demografski trendovi", Institut za migracije, Hrvatski studiji Sveučilišta u Zagrebu 2007.

Torrey ističe da gospodarstvo, više nego demografski trendovi, utječe na produktivnost, stavove i društvenu održivost. "Demografija ne predstavlja sudbinu (suprotno je tvrdio August Comte, sociolog 19. st. nap.), te se također vrlo sporo mijenja. Demografija se može nadvladati stvarima koje se kreću mnogo brže. Financijska tržišta nadilaze sve što demografija čini". Što se tiče pitanja sigurnosti, Barbara Torrey kaže da se nacionalne vojne snage mogu nadopuniti stranim snagama. Stručnjaci se slažu da će se europske zemlje sve više oslanjati na imigrante da popune manjak radne snage.

Europska unija je nedavno predstavila plan za privlačenje 20 milijuna imigranta tako što bi bili ublaženi uvjeti za izdavanje radne dozvole, tzv. plave karte.

Postojeće stanje može se dijagnosticirati na sljedeći način:

- Produženje životnoga vijeka zahvaljujući socijalno medicinskom standardu, 
- Porast broja radnika preko 60 godina bit će zaustavljen tek oko 2030. godine.

- Niski prirodni priraštaj.

Stanovništvo Evrope

\begin{tabular}{|l|l|l|l|}
\hline $\begin{array}{l}\text { Eurostat scenario, } \\
\text { EU-25 } \\
\text { (u tisućama) }\end{array}$ & $2005-2050$ & $2005-2010$ & $2010-2030$ \\
\hline Ukupna populacija & $\begin{array}{l}-2.1 \% \\
(-9642)\end{array}$ & $\begin{array}{l}+1.2 \% \\
(+5444)\end{array}$ & $\begin{array}{l}+1.1 \% \\
(+4980)\end{array}$ \\
\hline Djeca (0-14) & $\begin{array}{l}-19.4 \% \\
(-14415)\end{array}$ & $\begin{array}{l}-3.2 \% \\
(-2391)\end{array}$ & $\begin{array}{l}-8.9 \% \\
(-6411)\end{array}$ \\
\hline Mladi (14-24) & $-25.0 \%$ & $-4.3 \%$ & $-12.3 \%$ \\
$(-14441)$ & $(-2488)$ & $(-6815)$ \\
\hline Mladi odrasli (25-39) & $\begin{array}{l}-25.8 \% \\
(-25683)\end{array}$ & $-4.1 \%$ & $-16.0 \%$ \\
$(-4037)$ & $(-15271)$ \\
\hline Odrasli (40-54) & $-19.5 \%$ & $+4.2 \%$ & $-10.0 \%$ \\
$(+19125)$ & $(+4170)$ & $(+10267)$ \\
\hline Stariji zaposleni (55- & $+8.7 \%$ \\
$64)$ & $+4538)$ & $(+9.6 \%$ & $+15.5 \%$ \\
$(+5024)$ & $+8832)$ \\
\hline Stari (65-79) & $+44.1 \%$ \\
$(+25458)$ & $\begin{array}{l}+3.4 \% \\
(+1938)\end{array}$ & $\begin{array}{l}+37.4 \% \\
(+22301)\end{array}$ \\
\hline Jako stari (80+) & $+180.5 \%$ & $+17.1 \%$ & $+57.1 \%$ \\
$(+34026)$ & $(+3229)$ & $(+12610)$ \\
\hline
\end{tabular}

Izvor: Europeean Commission (2005.) Green Paper "Confronting demographic change: a new solidarity between the generations, preuzeto od Prof.dr. sc. Anđelko Milardović "Globalizacija i demografski trendovi", Institut za migracije, Hrvatski studiji Sveučilišta u Zagrebu 2007.

\section{Globalni demografski trendovi}

Globalne demografske trendove prikazuju sledeći grafikoni: 
Grafikon br.1:

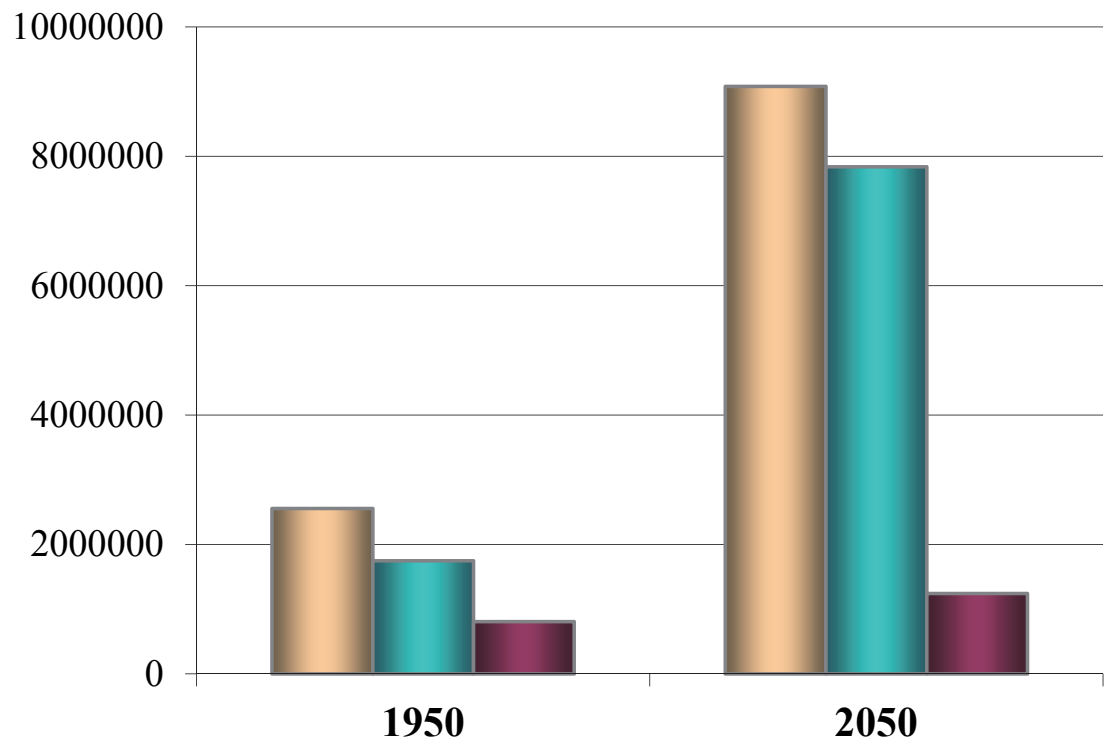

$\square$ svijet $\square$ manje razvijene zemlje $\quad$ razvijene zemlje

Izvor: Prof.dr. sc. Anđelko Milardović «Globalizacija i demografski trendovi«, Institut za migracije, Hrvatski studiji Sveučilišta u Zagrebu, 2007.

- Demografska dimenzija globalizacije relevantna je za razumijevanje populacijskih kretanja u svijetu pod utjecajem druge modernizacije i globalnog društva rizika.

- Na globalnoj razini uočava se trend povećanja svjetskog stanovništva do 2050. na 9,4 milijarde ljudi, od čega će 7,8 milijardi svjetske populacije pripadati nerazvijenim zemljama.

- Nerazvijene zemlje imaju značajnu stopu populacijskoga rasta tako da neke moraju voditi kontroliranu populacijsku politiku.

- Demografska dimenzija globalizacije pokazuje njezina dva lica. Ono prvo lice bogatih zemalja s depopulacijskim trendom (Zapad), i ono drugo siromašno s hiperpopulacijom. 
- Privremeni dobitnici globalizacije na dugi rok (razvijeni i Zapad), zbog depopulacijskog trenda, do 2050. smatrat će se gubitnicima.

Grafikon broj 2: Evropa i svijet 1970 - 2030: udio svjetskih regija u ukupnoj svjetskoj populaciji

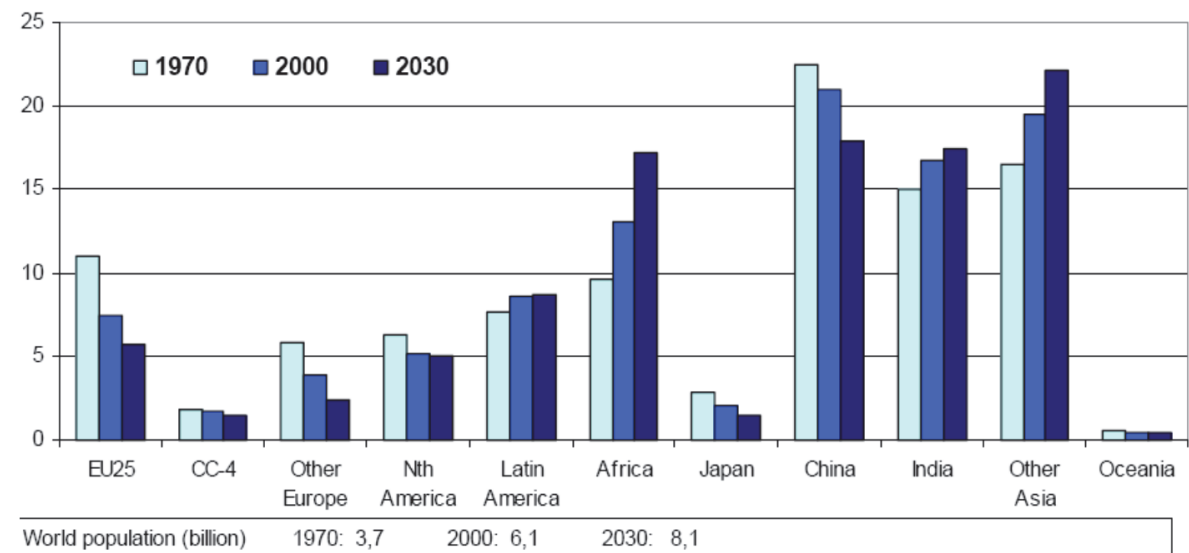

Izvor: U.S.Census Bureau, Global Population Profile:2002, table A4,page 1, preuzeto od Prof.dr. sc. Anđelko Milardović "Globalizacija i demografski trendovi", Institut za migracije, Hrvatski studiji Sveučilišta u Zagrebu, 2007.

$\mathrm{Na}$ nepovoljne demografske trendove, Evropska komisija ima sljedećih pet prijedloga:

1) Promoviranje demografske obnove.

2) Promoviranje zapošljavanja u Evropi kroz veći broj poslova i duži radni vijek.

3) Zalaganje za produktivniju i dinamičniju Evropu.

4) Prihvaćanje i integriranje imigranata u Evropi.

5) Održive javne financije u Evropi koje će jamčiti adekvatnu socijalnu sigurnost i jednakost među generacijama. 


\section{Zaključci}

- Definisanje demografskog starenja svodi se na utvrđivanje tempa povećanja i nivoa učešća stanovništva starog 60 ili 65 i više godina $u$ ukupnom stanovništvu.

- Direktan utjecaj na demografsku strukturu stanovništva imaju rađanje (natalitet) i trajanje ljudskog života (očekivano trajanje životnog vijeka) i smrtnost (mortalitet) ljudi.

- Na globalnoj razini uočava se trend povećanja svjetskog stanovništva do 2050. na 9,4 milijardi ljudi, od čega će 7,8 milijardi svjetske populacije pripadati nerazvijenim zemljama.

- Ljudski faktor - stanovništvo, njegova veličina, spolna i starosna struktura, obrazovni nivo i radna sposobnost, natalitet i mortalitet, predstavljaju osnovne pokazatelje stanja i odnosa, mogućnosti i ekonomskog razvoja, a samim tim pravca i cilja socijalne politike neke zemlje, ali i društva u globalu.

- Socijalna i populaciona politika su međusobno povezane, isprepletene i djeluju zajednički. Važno je naglasiti da demografski procesi predstavljaju sve složenije pitanje koje socijalna, populaciona i druge politike treba $\mathrm{u}$ budućnosti da rješavaju.

- Zaključak sa Svjetske skupštine o starenju (Beč, 1982) je da postoji velika vjerovatnoća da će 21. vijek, biti vijek starih ljudi. Samim tim u porastu će biti i potreba za obezbjeđivanjem materijalne sigurnosti, prije svega penzija, ali i zdravstvene i socijalne zaštite. Potreba za solidarnim odnosima između generacija u budućnosti bit će od velike važnosti.

- Društvo je dužno da starim ljudima obezbijedi dostojne uslove za život i zadovoljenje njihovih osnovnih potreba. $U$ tome veliku ulogu imaju vjerske zajednice i lokalne zajednice u kojima starije osobe žive i provode svoje posljednje dane života. 


\section{Literatura:}

1. Bouillet, D. (2003): Mogućnosti izvaninstitucionalnih oblika skrbi o starijim osobama, Revija za socijalnu politiku, Svezak 10, Br. 3, str. 321-333.

2. Burić, O., ur. (1980) Porodica i društveni sistem. Institut za socijalnu politiku. Beograd.

3. Dobrašin, M. (2007): Oprečni populacijski trendovi u Europi i SAD-u prijetnja suradnji, http:/www.poslovni.hr/.

4. Gavrilović, A. (2005): Socijalna politika, Filozofski fakultet, Banja Luka

5. Gavrilović, A. (2007): Lokalna samouprava i populaciona politika, u: "Aktiviranje lokalne samouprave u populacionoj politici AP Vojvodine", Izvršno veće Vojvodine i pokrajinski sekretarijat za demografiju, porodicu i društvenu brigu o deci, Novi Sad.

6. Lučanin, D. Despot Lučanin, J. Havelka, M. (2000): Potrebe starijih osoba za cjelovitim uslugama skrbi u lokalnoj zajednici. Revija za socijalnu politiku 7 (1), 19-27.

7. Jakič-Kozarčanin, L. (2003): Starost između države i porodice, Službeni glasnik, Beograd,

8. Mesec, B. (2000): Stariji ljudi u Sloveniji, Revija za socijalnu politiku, Svezak 7, Br. 1, str. 43-53.

9. Puljiz, V. (2000): Sustavi socijalne politike, Pravni fakultet Sveučilišta Zagreb,.

10. Smolić-Krković, N. (1974): Gerontologija: priručnik za socijalne radnike/. Impresum: Zagreb: Savez društava socijalnih radnika SRH.

11. Milardović, A. (2007): Globalizacija i demografski trendovi, Institut za migracije, Hrvatski studiji Sveučilišta u Zagrebu, Zagreb.

12. Nicholas Eberstadt - Wikipedia, en.wikipedia.org/wiki/Nicholas_Eberstadt

13. Međunarodni dan starih osoba, http://www.pravaustarosti.com/aktivnosti/45-meunarodni-dan-starijihosoba 
Hariz Šarić, Sena Družić, Alisabri Šabani

\section{AGING AND OLD AGE - THE PRESENT AND THE FUTURE OF POPULATION}

\section{Abstract}

Population aging is one of the most important issues of the future and social development of many countries. The fact is that the adaptation to the age depends not only on biological and psychological factors, but also by external factors, such as social environment, family circumstances, housing conditions and support systems in some environments exist and are aimed at helping the elderly. At the global level we can see the trend of increasing world population in 2050 to 9.4 billion people, of which 7.8 billion world population belong to developing countries. Data on demographic trends in most developed countries suggest the need for new scientific, and political approach in shaping the future strategy of protection for the elderly. While Europe's population is aging, which in the coming years expected population decline in Europe, in the United States there is an opposite trend. The demographic dimensions of globalization shows its two faces. The former face of rich countries with depopulation trend (West), and the other poor with hiperpopulacijom. Global trends should move in the direction of promoting demographic renewal, employment in Europe through a number of jobs and longer working lives, acceptance and integration of immigrants in Europe and sustainable public finances in Europe which will guarantee adequate social security and equity between generations.

Keywords: aging, old age, an aging population, social policy, social security 
الدكتور حارس شاريتش؛، م. ثناء دروجيتشْ، الدكتور علي صبري شعباني"

التقدم في السن والشيخوخة - حاضر السكان ومستقبلهم

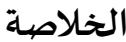

يعتبر التقدم في السن لدى السكان واحدة من مسائل مهمة للمستقبل والتنمية

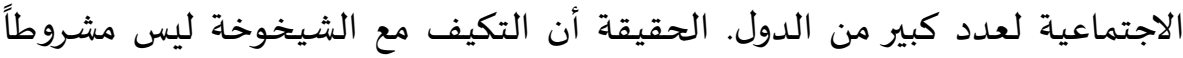


العائلية والسكنية ونظم الدعم التي توجد في بعض المجتمعات وهي موجهة لدعم المسنين.

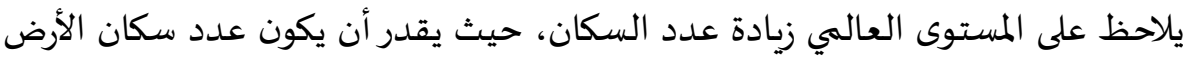

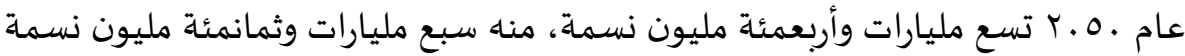

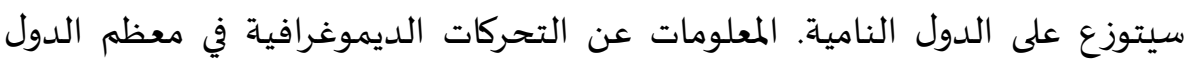
المتقدمة تشير إلى معالجة علمية جديدة، بالإضافة إلى المعالجة السياسية في تكوين

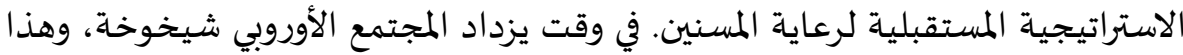
يعني تقليص عدد سكان أوروبا في السنوات القادمة، فإن الولايات الأمريكية المتحدة

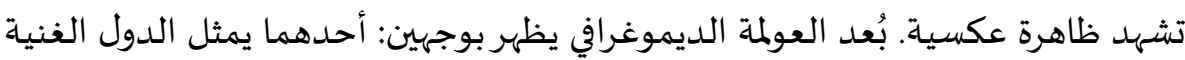
حيث يتناقص عدد سكانها والآخر الفقير حيث التزايد السكاني الكبير. ينبغي أن يكون هناك التوجه العالمي نحو ترويج إعادة البناء الديموغرافي والتوظيف في أوروبا من خلال عدد أكبر من الأعمال والعمر العملي الأطول وقبول ندول

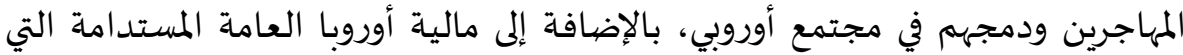
ستضمن الأمان الاجتماعي المناسب والمسـاواة بين الأجيال.

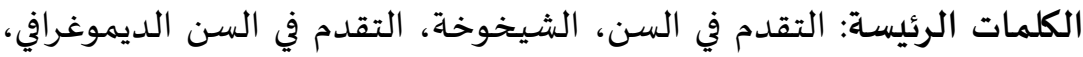

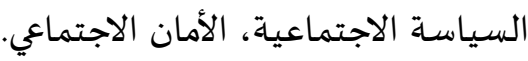

؛ كلية الفلسفة بجامعة توزلا.

كلية التربية الإسلامية في بهاتش.

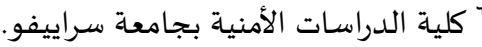

